\title{
Purified glycerin diets for broilers from 8 to 42 days old $^{1}$
}

\section{Glicerina purificada em dietas para frangos de corte dos 8 aos 42 dias de idade}

\author{
Mônica Calixto da Silva ${ }^{2 *}$; Roberta Gomes Marçal Vieira Vaz ; Kênia Ferreira \\ Rodrigues $^{3}$; Luciano Fernandes Sousa ${ }^{3}$; Marilú Santos Sousa ${ }^{3}$; Gerson Fausto da \\ Silva $^{3}$; Flávia Luzia Rodrigues Fonseca ${ }^{3}$; Mayara da Cruz Ribeiro ${ }^{4}$; Carla Fonseca \\ Alves Campos ${ }^{4}$; Latóya de Sousa Bezerra ${ }^{5}$
}

\begin{abstract}
Here we evaluate the technical viability of including purified glycerin in balanced diets for broilers from 8 to 42 days old. For this, we used 1608 -day-old broiler chickens from the Cobb $500 \AA$ lineage, distributed in a completely randomized design (CRD) with four treatments $(0,2,4$, and $6 \%$ of purified glycerin inclusion) and four replicates of ten birds. We evaluated feed intake, weight gain, feed conversion, final weight, organs biometry (heart, liver, gizzard and small intestine), carcass yield, special cuts yields (thigh, drumstick, and breast), meat color, and protein and fat deposition in the breast muscle. The purified glycerin inclusion levels in diets influenced $(\mathrm{p}<0.05)$ weight gain, feed conversion, and broiler weight at 42 days, with no effect ( $p>0.05)$ on feed intake (FI). Similarly, there was no effect $(p>0.05)$ on carcass and special cuts yields. The purified glycerin inclusion levels did not influence $(p>0.05)$ the relative gizzard weight, nor the relative small intestine weight and length. However, the purified glycerin inclusion levels did affect the relative heart and liver weights $(\mathrm{p}<0.05)$. The purified glycerine inclusion levels in diets did not affect $(\mathrm{p}>0.05)$ lightness $\left(\mathrm{L}^{*}\right)$, redness $\left(\mathrm{a}^{*}\right)$, yellowness $\left(\mathrm{b}^{*}\right)$ values, $\mathrm{pH}$, or protein deposition, but did increases $(\mathrm{p}<0.05)$ fat deposition in breast muscle. Based on our findings, we propose that the inclusion of $6 \%$ purified glycerin in diets is technically feasible for broilers of 8 to 42 days old.
\end{abstract}

Key words: Biodiesel co-products. Fat deposition. Meat quality. Protein deposition. Productive performance.

\section{Resumo}

Objetivou-se neste trabalho avaliar a viabilidade técnica da inclusão de glicerina purificada em dietas balanceadas para frangos de corte, dos 8 aos 42 dias de idade. Foram utilizados 160 pintos de corte, com 8 dias, da linhagem Cobb $500^{\circledR}$, distribuídos em delineamento experimental inteiramente casualizado

Parte da Tese de Doutorado da primeira autora.

2 Discente de Pós-Doutorado, Programa de Pós-Graduação em Ciência Animal Tropical, Universidade Federal do Tocantins, UFT, Araguaína, TO, Brasil. E-mail: monicalixto_@hotmail.com

3 Profs. Drs., Departamento de Zootecnia, Escola de Medicina Veterinária e Zootecnia, UFT, Araguaína, TO, Brasil. E-mail: betagmvvaz@yahoo.com.br; rodrigueskf@mail.uft.edu.br; luciano.sousa@mail.uft.edu.br; mariluzoo@hotmail.com; gerson@ mail.uft.edu.br; flrf@ outlook.com

4 Discentes de Doutorado, Programa de Pós-Graduação em Ciência Animal Tropical, UFT, Araguaína, TO, Brasil. E-mail: mayzoo@hotmail.com; carlafazoo@hotmail.com

5 Discente de Mestrado, Programa de Pós-Graduação em Ciência Animal Tropical, UFT, Araguaína, TO, Brasil. E-mail: latoyanina@hotmail.com

Author for correspondence. 
(DIC), com quatro tratamentos $(0,2,4$ e $6 \%$ de inclusão de glicerina purificada) e quatro repetições de dez aves. Foram avaliados o consumo de ração, ganho de peso, conversão alimentar, peso final, biometria dos órgãos (coração, fígado, moela e intestino delgado), rendimento de carcaça, rendimentos de cortes nobres (coxa, sobrecoxa e peito), coloração e a deposição de proteína e deposição de gordura da carne do peito. Os níveis de inclusão de glicerina purificada nas dietas influenciaram $(p<0,05) o$ ganho de peso, a conversão alimentar e o peso das aves aos 42 dias, não havendo efeito $(p>0,05)$ sobre o consumo de ração. Da mesma forma, não houve efeito $(p>0,05)$ sobre os rendimentos de carcaça e cortes nobres. Os níveis de inclusão de glicerina purificada não influenciaram $(p>0,05)$ os pesos relativos da moela, nem o peso relativo e/ou comprimento do intestino delgado. Entretanto, observou-se efeito $(\mathrm{p}<0,05)$ sobre o peso relativo do coração e fígado. Os níveis de inclusão de glicerina purificada nas dietas não afetaram $(\mathrm{p}>0,05)$ os valores de luminosidade $\left(\mathrm{L}^{*}\right)$, vermelho $\left(\mathrm{a}^{*}\right)$, amarelo $\left(\mathrm{b}^{*}\right), \mathrm{pH}$ e a deposição de proteína, mas, aumentou de maneira linear $(\mathrm{p}<0,05)$ a deposição de gordura da carne de peito. A inclusão de até $6 \%$ de glicerina purificada nas dietas mostrou-se tecnicamente viável para frangos de corte dos 8 aos 42 dias de idade.

Palavras-chave: Coprodutos do biodiesel. Deposição de gordura. Desempenho produtivo. Deposição de proteína. Qualidade de carne.

\section{Introduction}

The high costs of feeding broiler chickens has aroused interest in new alternative sources of food, which can partially replace energy and protein foods in the diet, aiming at minimizing the costs of nutrition and, consequently, production (FREITAS et al., 2017; HENZ et al., 2013;2014; SILVA et al., 2017).

Foods derived from agro-industrial processing have gained prominence in animal nutrition, including glycerine, a production co-product of biodiesel. Biological tests carried out to verify the energy content of glycerines have demonstrated their efficiency as an energy source for birds (ABDELSAMEE et al., 2010; DOZIER et al., 2008; 2011; JUNG; BATAL, 2011; OLIVEIRA et al., 2013).

According to Oliveira et al. (2013), glycerin has a good gross energy content (relative to maize) that is highly metabolizable and, thus, can be considered for use in poultry feed. Topal and Ozdogan (2013) evaluated the effects of different amounts of glycerol $(0,4$, and $8 \%)$ on the variables of performance, organ weight, and chemical composition of broiler muscles from 1 to 42 days of age and concluded that glycerin can be used as a source of energy up to $8 \%$, especially in the 1 to 21 days phase, without compromising bird performance. Likewise, Mclea et al. (2011) tested different glycerin inclusion levels
(3.3, 6.7, and 10.0\%) in broiler diets and found that inclusion of up to $6.7 \%$ did not cause negative effects on broiler diets, productive performance, and digestibility of nutrients.

However, there is yet no clear consensus on the ideal level of food inclusion in the diets, due to the different raw materials and catalysts used to produce biodiesel, which cause excesses of some minerals that may affect its composition and limit its use in the feeding of birds (FREITAS et al., 2017; ROMANO et al., 2014).

In addition, excessive levels of glycerin in diets can decrease glycerol metabolism capacity in the body, and consequently increase excretion by birds, favoring greater bed humidity (GIANFELICI et al., 2011).

Here, we aimed to evaluate the technical viability of the inclusion of purified glycerin in balanced diets for broilers from 8 to 42 days of age.

\section{Material and Methods}

The trial was conducted at the Poultry Research Centre of the School of Veterinary Medicine and Animal Science, Federal University of Tocantins, Araguaína - TO, from September $29^{\text {th }}$ to November $10^{\text {th }} 2015$. The study was conducted in accordance with the statements of the Ethics 
in Animal Use Committee, Federal University of Tocantins (CEUA-UFT) under the protocol number 23101.000830/2014-16.

A total of 160 male Cobb $500 \AA$ broiler chicks, raised up to the 7 th day of life, were used according to the lineage recommendations. The birds were fed at will with diets formulated with corn and soybean meal according to the nutritional requirements recommended by Rostagno et al. (2011) for broiler chickens of medium performance males, from 1 to 7 days of age. On the 8th day, birds with a mean weight of $208 \pm 16.78 \mathrm{~g}$ were homogenized, and the treatments were distributed in a completely randomized experimental design (DIC), with four treatments $(0,2,4$, and $6 \%$ inclusion of purified glycerin), with four replicates of ten birds per experimental unit.

Broilers were housed in an experimental shed with 16 boxes of $2 \mathrm{~m}^{2}$, supplied with tubular feeders and pendulum drinkers. Replenishing of feeders and cleaning of drinkers were performed twice a day to ensure free access to water and feed throughout the experimental period.

Until the $14^{\text {th }}$ day old, broilers were heated artificially, using incandescent lamps (60 W) located inside the boxes. Environmental conditions inside the facility during the experimental period were monitored and recorded daily every $5 \mathrm{~min}$ using HOBO Data Loggers OnSet ${ }^{\circledR}$ ware Version 3.4.1. The devices were placed at the half height in the boxes to obtain data of temperature and relative humidity. The average air maximum and minimum temperatures inside the facility during the experimental period were $25.6,32.8$, and $20.8{ }^{\circ} \mathrm{C}$ respectively, and the relative humidity was $85 \%$.

The experimental diets were calculated considering the purified glycerin chemical composition (Table 1) and the nutritional requirements for medium performance male broilers following the Rostagno et al. (2011) recommendations from 8 to 21 (Table 2) and from 22 to 42 days of age (Table 3).

Table 1. Composition of purified glycerin used in the formulation of experimental diets.

\begin{tabular}{lc}
\hline Nutrients and energy & Purified glycerin $^{1}$ \\
\hline Crude protein $(\%)^{2}$ & 0.23 \\
Metabolizable energy $(\mathrm{kcal} / \mathrm{kg})^{3}$ & 3560 \\
${\text { Dry matter }(\%)^{4}}^{4}$ & 89.98 \\
Ether extract $(\%)^{4}$ & 1.19 \\
Mineral matter $(\%)^{4}$ & 7.86 \\
Methanol $(\mathrm{g} / \mathrm{kg})^{4}$ & Less than 0.1 \\
$\mathrm{Glycerol}(\%)^{4}$ & 80.4 \\
$\mathrm{NaCl}(\%)^{4}$ & 7.47 \\
$\mathrm{Na}(\%)^{4}$ & 2.96 \\
\hline
\end{tabular}

${ }^{1}$ Glycerin from the processing of soybeans, sold in southern Brazil.

${ }^{2}$ Rostagno et al. (2011).

${ }^{3}$ Analysis conducted at the Animal Nutrition Laboratory from the School of Veterinary Medicine and Animal Science, Federal University of Tocantins.

${ }^{4}$ Approximate values supplied by the manufacturer. 
The evaluated parameters were growth curve (g), growth rate (days), feed intake (FI), weight gain (WG), feed conversion ratio (FC), final weight (FW), organ biometry (heart, liver, gizzard), weight and/or length of the small intestine, carcass yield (CY), special cuts yield (thigh, drumstick and breast), color of breast muscle ( $\mathrm{L}^{*}=$ lightness, $\mathrm{a}^{*}=$ redness, $\mathrm{b}^{*}=$ yellowness), $\mathrm{pH}$, protein deposition and fat deposition.

The birds were weighed at the beginning and at the end of the experimental period for GP determination. The $\mathrm{CR}$ was calculated considering the amount of feed supplied and the leftovers in the feeders. The AC was obtained by the ratio between the consumption of ingested ration and the weight gain of the birds during the experimental period.

At 42 days of age, two broilers per repetition with body weights within $\pm 5 \%$ of the average were fasted for $12 \mathrm{~h}$ and then slaughtered by cervical dislocation. Subsequently, they were subjected to bleeding, scalding, plucking, and evisceration procedures. Relative weights of whole carcasses (with legs, neck, and head) and special cuts (thigh, drumstick, and breast) were determined.

Table 2. Composition of experimental diets containing increasing levels of purified glycerin for broilers from 8 to 21 days of age.

\begin{tabular}{|c|c|c|c|c|}
\hline \multirow{2}{*}{ Ingredients } & \multicolumn{4}{|c|}{ Levels of purified glycerin (\%) } \\
\hline & 0 & 2 & 4 & 6 \\
\hline Corn & 59.119 & 56.977 & 54.835 & 52.692 \\
\hline Soybean meal (45\%) & 34.741 & 35.116 & 35.493 & 35.868 \\
\hline Purified glycerin & 0.000 & 2.000 & 4.000 & 6.000 \\
\hline Dicalcium phosphate & 1.508 & 1.511 & 1.513 & 1.516 \\
\hline Soybean oil & 2.157 & 2.077 & 1.997 & 1.917 \\
\hline Limestone & 0.924 & 0.923 & 0.919 & 0.917 \\
\hline Salt & 0.482 & 0.333 & 0.185 & 0.037 \\
\hline DL-Methionine & 0.287 & 0.289 & 0.292 & 0.294 \\
\hline L-Lysine $\mathrm{HCl}$ & 0.218 & 0.211 & 0.203 & 0.196 \\
\hline L-Threonine & 0.064 & 0.063 & 0.063 & 0.063 \\
\hline Mineral and vitamin supplement ${ }^{1}$ & 0.500 & 0.500 & 0.500 & 0.500 \\
\hline Total & 100.00 & 100.00 & 100.00 & 100.00 \\
\hline \multicolumn{5}{|c|}{ Calculated nutritional composition } \\
\hline Metabolizable energy $(\mathrm{kcal} / \mathrm{kg})$ & 3000 & 3000 & 3000 & 3000 \\
\hline Crude protein $(\%)$ & 20.80 & 20.80 & 20.80 & 20.80 \\
\hline Calcium $(\%)$ & 0.819 & 0.819 & 0.819 & 0.819 \\
\hline Available Phosphorus (\%) & 0.391 & 0.391 & 0.391 & 0.391 \\
\hline Digestible Lysine (\%) & 1.174 & 1.174 & 1.174 & 1.174 \\
\hline Digestible Methionine + Cysteine $(\%)$ & 0.846 & 0.846 & 0.846 & 0.846 \\
\hline Digestible Methionine (\%) & 0.562 & 0.562 & 0.563 & 0.564 \\
\hline Digestible Threonine (\%) & 0.763 & 0.763 & 0.763 & 0.763 \\
\hline Sodium $(\%)$ & 0.210 & 0.210 & 0.210 & 0.210 \\
\hline Potassium (\%) & 0.808 & 0.808 & 0.809 & 0.809 \\
\hline
\end{tabular}


continuation

\begin{tabular}{lllll} 
Chlorine $(\%)$ & 0340 & 0.251 & 0.161 & 0.072 \\
Electrolyte balance $(\mathrm{mEq} / \mathrm{kg})^{2}$ & 202.1 & 227.2 & 252.9 & 277.9 \\
\hline
\end{tabular}

${ }^{1}$ Composition/ton: Folic Acid: $150.00 \mathrm{mg}$; Cobalt: $178.00 \mathrm{mg}$; Copper: 2,675.00 mg; Choline: 120.00 g; Colistin: 2,000.00 mg; Iron: $11.00 \mathrm{~g}$; Iodine: $535.00 \mathrm{mg}$; Manganese: $31.00 \mathrm{~g}$; Mineral matter: $350.00 \mathrm{~g}$; Niacin: 7,200.00 mg; Nicarbazin: $24.00 \mathrm{~g}$; Calcium Pantothenate: 2,400.00 mg; Selenium: $60.00 \mathrm{mg}$; Vitamin A: 1,920,000.00 IU; Vitamin B1: $300.00 \mathrm{mg}$; Vitamin B12: 3,600.00 mg; Vitamin B2: 1,200.00 mg; Vitamin B6: 450.00 mg; Vitamin D3: 360,000.00 IU; Vitamin E: 3,600.00 IU; Vitamin H: $18.00 \mathrm{mg}$; Vitamin K: $480.00 \mathrm{mg}$; Zinc: $22.00 \mathrm{~g}$.

${ }^{2}$ Calculated according to Mongin (1981): Electrolyte Balance $=\left(\mathrm{mg} / \mathrm{kg}\right.$ of dietary $\left.\mathrm{Na}^{+} / 22.990\right)+(\mathrm{mg} / \mathrm{kg}$ of dietary K$/ 39.102)-$ $\left(\mathrm{mg} / \mathrm{kg}\right.$ of dietary $\left.\mathrm{Cl}^{-} / 35.453\right)$.

The edible viscera (gizzard, heart, and liver) and the small intestine were collected during evisceration. Subsequently, they were cleaned, dried on paper towels, and weighed separately on a precision scale. From the gizzard, all the adhered fat, its contents, and the koilin membrane were removed. In addition to weight, the length of the small intestine, from the beginning of the duodenum to the ileocecal junction, was measured. The relative weight of plucked and eviscerated carcass was calculated in relation to fasting weight. The relative weights of the cuts, edible viscera, and small intestine were obtained in relation to plucked and eviscerated carcass.

In the raw breast meat (boneless, skinless, without ligaments and fat) the $\mathrm{pH}$ and color of the meat were evaluated by the CIELAB system ( $\mathrm{L}^{*}=$ lightness, $\mathrm{a}^{*}=$ redness, $\mathrm{b}^{*}=$ yellowness) with a colorimeter $\left(\right.$ Chroma meter $\left.{ }^{\circledR}\right)$. The readings were performed at three different points of the musculature and $\mathrm{pH}$ determination was performed by means of penetration electrode, inserted directly into the meat.

Table 3. Composition of experimental diets containing increasing levels of purified glycerin for broilers from 22 to 42 days of age.

\begin{tabular}{lcccc}
\hline \multirow{2}{*}{ Ingredients } & \multicolumn{4}{c}{ Levels of purified glycerin (\%) } \\
\cline { 2 - 5 } Corn & 0 & 2 & 4 & 6 \\
Soybean meal (45\%) & 64.039 & 61.843 & 59.647 & 57.451 \\
Purified glycerin & 29.434 & 29.821 & 30.206 & 30.592 \\
Dicalcium phosphate & 0.000 & 2.000 & 4.000 & 6.000 \\
Soybean oil & 1.172 & 1.174 & 1.177 & 1.179 \\
Limestone & 3.078 & 3.040 & 3.005 & 2.968 \\
Salt & 0.817 & 0.815 & 0.812 & 0.810 \\
DL-Methionine & 0.450 & 0.302 & 0.154 & 0.006 \\
L-Lysine HCl & 0.248 & 0.250 & 0.253 & 0.255 \\
L-Threonine & 0.214 & 0.207 & 0.199 & 0.192 \\
Mineral and vitamin supplement ${ }^{1}$ & 0.048 & 0.048 & 0.047 & 0.047 \\
\hline Total & 0.500 & 0.500 & 0.500 & 0.500 \\
\hline
\end{tabular}

continue 


\begin{tabular}{lcccc}
\hline & Calculated nutritional composition & & \\
Metabolizable energy (kcal/kg) & 3125 & 3125 & 3125 & 3125 \\
Crude protein (\%) & 18.75 & 18.75 & 18.75 & 18.75 \\
Calcium (\%) & 0.685 & 0.685 & 0.685 & 0.685 \\
Available Phosphorus (\%) & 0.320 & 0.320 & 0.320 & 0.320 \\
Digestible Lysine (\%) & 1.044 & 1.04 & 1.044 & 1.044 \\
Digestible Methionine + Cysteine (\%) & 0.762 & 0.762 & 0.762 & 0.762 \\
Digestible Methionine (\%) & 0.501 & 0.502 & 0.503 & 0.504 \\
Digestible Threonine (\%) & 0.678 & 0.678 & 0.678 & 0.678 \\
Sodium (\%) & 0.197 & 0.197 & 0.197 & 0.197 \\
Potassium (\%) & 0.725 & 0.725 & 0.726 & 0.727 \\
Chlorine (\%) & 0.322 & 0.232 & 0.143 & 0.053 \\
Electrolyte balance (mEq/kg) & 180.3 & 205.7 & 231.0 & 256.7 \\
\hline
\end{tabular}

${ }^{1}$ Composition/ton: Folic Acid: $120.00 \mathrm{mg}$; Cobalt: $179.00 \mathrm{mg}$; Copper: 2,688.00 mg; Choline: 108.00 g; Iron: $11.00 \mathrm{~g}$; Iodine: $537.00 \mathrm{mg}$; Lincomycin $800.00 \mathrm{mg}$; Manganese: $31.00 \mathrm{~g}$; Mineral matter: $350.00 \mathrm{~g}$; Niacin: 6,000.00 mg; Calcium Pantothenate: 1,920.00 mg; Salinomycin: 12.00 g; Selenium: $54.00 \mathrm{mg}$; Moisture $80.00 \mathrm{~g}$; Vitamin A: 1,500,000.00 IU; Vitamin B1: $300.00 \mathrm{mg}$; Vitamin B12: 2,800.00 mg; Vitamin B2: $960.00 \mathrm{mg}$; Vitamin B6: 450.00 mg; Vitamin D3: 300,000.00 IU; Vitamin E: 3,000.00 IU; Vitamin H: $20.00 \mathrm{mg}$; Vitamin K: $480.00 \mathrm{mg}$; Zinc: $22.00 \mathrm{~g}$.

${ }^{2}$ Calculated according to Mongin (1981): Electrolyte Balance $=\left(\mathrm{mg} / \mathrm{kg}\right.$ of dietary $\left.\mathrm{Na}^{+} / 22.990\right)+\left(\mathrm{mg} / \mathrm{kg}\right.$ of dietary K $\left.\mathrm{K}^{+} / 39.102\right)-$ $\left(\mathrm{mg} / \mathrm{kg}\right.$ of dietary $\left.\mathrm{Cl}^{-} / 35.453\right)$.

The breasts were cut in half and frozen in plastic bags. One of the separated halves was ground in an industrial meat grinder. The ground cuts were weighed, homogenized, and pre-dried in an oven at $55^{\circ} \mathrm{C}$ for $72 \mathrm{~h}$. Subsequently, they were ground in a knife-type mill and transported to the laboratory for analysis (crude protein and ether extract) according to Silva and Queiroz (2002).

Protein and fat deposition rates in breast meat ( $g$ /day) were calculated based on the slaughtering of an additional group of six one-day-old chicks, compared to those birds slaughtered at 42 days of age, according to the formulas described by Scherer et al. (2011).

To determine the weight loss during cooking, breast fillets were weighed and baked in an electric oven at $170^{\circ} \mathrm{C}$ until reaching the internal temperature of $40{ }^{\circ} \mathrm{C}$. Subsequently, they were turned once to reach the internal temperature of $70^{\circ} \mathrm{C}$. The samples were placed on absorbent paper for cooling to a temperature of 20 to $25^{\circ} \mathrm{C}$ and then weighed again to determine the weight loss during cooking. Finally, the samples were kept under refrigeration at $4{ }^{\circ} \mathrm{C}$ for $24 \mathrm{~h}$, according to the methodology adapted from Froning and Uijttenboogarte (1988).

To determine the shear force, cylindrical samples $(1.27 \mathrm{~cm}$ in diameter) were taken and placed with the fibers oriented perpendicular to the direction of plunger travel, using a Warner-Bratzler instrument.

The data were submitted to Normality tests (Cramer Von Mises) and homoscedasticity (Levene). The variables were subjected to regression analysis using polynomial models of first or second order, considering the inclusion level of purified glycerin as an independent variable. To check the adjustment of the equation, it was considered the significance of " $F$ " test for models, the significance of " $t$ " test for the parameters ( $\beta 0, \beta 1$ and $\beta 2)$ of the models, and the coefficient of determination $\left(\mathrm{R}^{2}=\mathrm{SS}\right.$ regression/ $\mathrm{SS}$ total), considering the significance level equal to or less than $5 \%$. Statistical analyses were performed with the aid of SISVAR statistical program. 


\section{Results and Discussion}

It was observed that the inclusion levels of purified glycerin in the diets influenced $(p<0.05)$ the weight gain (GP), the feed conversion (CA), and the weight of the birds at 42 days (P42d), with no effect $(\mathrm{p}>0.05)$ on feed intake (CR) (Table 4).

Table 4. Average feed intake (FI), weight gain (WG), feed conversion (FC) and weight at 42 days (W7d) in broilers from 8 to 42 days old according to the inclusion level of purified glycerin.

\begin{tabular}{|c|c|c|c|c|c|c|c|c|c|}
\hline \multirow{2}{*}{ Variables } & \multicolumn{4}{|c|}{ Purified glycerin inclusion level (\%) } & \multirow{2}{*}{ Mean } & \multicolumn{3}{|c|}{$\mathrm{P}$} & \multirow{2}{*}{$\mathrm{CV}^{1}(\%)$} \\
\hline & 0 & 2 & 4 & 6 & & LE & QE & LD & \\
\hline $\mathrm{FI}^{2}(\mathrm{~g})$ & 435.50 & 4427.00 & 4329.75 & 4481.25 & 4398.36 & 0.191 & 0.393 & 0.061 & 2.05 \\
\hline WG (g) & 2629.75 & 2712.50 & 2701.50 & 2756.00 & 2699.94 & 0.028 & 0.676 & 0.302 & 2.44 \\
\hline $\mathrm{FC}(\mathrm{g} / \mathrm{g})$ & 1.658 & 1.631 & 1.600 & 1.628 & 1.628 & 0.040 & 0.058 & 0.230 & 1.46 \\
\hline P42d (g) & 2835.00 & 2918.25 & 2907.75 & 2962.25 & 2905.81 & 0.027 & 0.670 & 0.302 & 2.26 \\
\hline
\end{tabular}

${ }^{1}$ Coefficient of variation $(\%)$.

${ }^{2} \hat{Y}=$ NS.

$\mathrm{LE}=$ linear effect; $\mathrm{QE}=$ quadratic effect $\mathrm{LD}=$ linearity deviation; $\mathrm{P}=$ probability of type $\mathrm{I}$ error at $5 \%$ using $\mathrm{F}$ test. Equation: $\mathrm{WG}(\mathrm{g})=2644.78+18.39 \mathrm{IL}\left(\mathrm{P}=0.028 ; \mathrm{r}^{2}=0.81\right) ; \mathrm{FC}(\mathrm{g})=144.25+1.875 \mathrm{IL}\left(\mathrm{P}=0.001 ; \mathrm{r}^{2}=0.79\right) ; \mathrm{FC}(\mathrm{g} / \mathrm{g})=1.09-0.0075 \mathrm{IL}$ $\left(\mathrm{P}=0 \mathrm{~L} 002 ; \mathrm{r}^{2}=0 \mathrm{~L} 79\right) ; \mathrm{P} 42 \mathrm{~d}(\mathrm{~g})=2850 \mathrm{~L} 13+18.55 \mathrm{IL}\left(\mathrm{P}=0.027 ; \mathrm{r}^{2}=0.82\right)$; in which $\mathrm{IL}=$ purified glycerin inclusion level $(\%)$.

The lack of effect on the CR of the birds may be related to the fact that the experimentais diets were formulated to be isoenergetic and isunutritive meeting the requirements of metabolizable energy $(\mathrm{kcal} / \mathrm{kg})$, regardless of the level of inclusion of purified glycerin. Thus, the voluntary consumption of feed by the birds is directly related to the energy level of the diets, which provided the balanced intake of metabolizable energy and crude protein by birds.

From the results obtained, it can be inferred that the levels of inclusion of purified glycerin in the diets improved the performance of the broilers, and it is possible to affirm that the inclusion of up to $6 \%$ does not affect the performance variables. Similar results were found by Freitas et al. (2017), who developed an experiment, using levels of 0,5 and $10 \%$ of glycerin in broilers fed from 1 to 42 days, and concluded that glycerin can be used in diets up to $5 \%$ without affecting the performance of the birds.

Similarly, Sehu et al. (2012) evaluated the 0, 5, and $10 \%$ levels of glycerin in broilers feeding and observed that the inclusion of up to $5 \%$ of the feed did not affect any of the performance characteristics during the total period of 1 to 42 days of growth.

It was observed that the levels of inclusion of purified glycerin in the diets did not affect $(p>$ 0.05 ) the relative carcass, thigh, supercox, breast, and protein deposition weights. However, there was an increasing dose dependent effect $(p<0.05)$ for the deposition of breast meat fat from chickens slaughtered at 42 days (Table 5). 
Table 5. Average carcass (CY), thigh (TCY), drumstick (DSCY), and breast (BY), protein deposition (PD), and fat deposition (FD) in the breast meat of broilers at 42 days of age according to the level of inclusion of purified glycerin.

\begin{tabular}{|c|c|c|c|c|c|c|c|c|c|}
\hline \multirow{2}{*}{ Variables } & \multicolumn{4}{|c|}{ Purified glycerin inclusion level (\%) } & \multirow{2}{*}{ Mean } & \multicolumn{3}{|c|}{$P$} & \multirow{2}{*}{$\begin{array}{l}C{ }^{1} \\
(\%)\end{array}$} \\
\hline & 0 & 2 & 4 & 6 & & LE & $\mathrm{QE}$ & LD & \\
\hline $\mathrm{CY}^{2}(\%)$ & 85.28 & 85.08 & 84.36 & 84.70 & 84.85 & 0.452 & 0.706 & 0.627 & 1.68 \\
\hline $\mathrm{TCY}^{3}(\%)$ & 12.14 & 11.88 & 11.84 & 12.11 & 11.98 & 0.904 & 0.199 & 0.935 & 3.27 \\
\hline $\operatorname{DSCY}^{4}(\%)$ & 12.28 & 12.67 & 12.80 & 12.85 & 12.65 & 0.183 & 0.570 & 0.892 & 4.60 \\
\hline $\mathrm{BY}^{5}(\%)$ & 35.93 & 37.15 & 36.31 & 36.14 & 36.38 & 0.949 & 0.379 & 0.439 & 4.17 \\
\hline $\mathrm{PD}^{6}$ (g/dia) & 5.18 & 5.16 & 5.14 & 5.36 & 5.20 & 0.311 & 0.312 & 0.619 & 4.54 \\
\hline FD (g/dia) & 1.19 & 1.31 & 1.39 & 1.41 & 1.33 & 0.001 & 0.195 & 0.873 & 4.11 \\
\hline
\end{tabular}

${ }^{1}$ Coefficient of variation $(\%)$.

$2,3,4,5,6 \hat{\mathrm{Y}}=\mathrm{NS}$.

$\mathrm{LE}=$ linear effect; $\mathrm{QE}=$ quadratic effect; $\mathrm{LD}=$ linearity deviation; $\mathrm{P}=$ probability of type $\mathrm{I}$ error at $5 \%$ using $\mathrm{F}$ test. Equation: $\mathrm{FD}$ $(\mathrm{g} /$ day $)=1.213+0.0382 \mathrm{IL}\left(\mathrm{P}=0.001 ; \mathrm{r}^{2}=0.94\right)$; in which $\mathrm{IL}=$ purified glycerin inclusion level $(\%)$.

These results are in agreement with those found by Sehu et al. (2013) and Silva et al. (2012), who observed that the inclusion of up to $5 \%$ glycerin in broiler diets did not affect carcass yields and noble cuts.

The results of fat deposition in the breast meat are in agreement with the reports of Oliveira Neto et al. (2000), who verified a linear increase in the fat content of the carcass of broiler chickens as a result of the increase in the energy levels of the ration. Divergent results were found by Henz et al. (2014), who evaluated different levels $(0,3,6,9,12$, and $15 \%$ ) of glycerin in broiler feed and did not observe effects on the levels of fat and protein deposition in broiler carcasses of 1 to 21 days of age.

Eyng et al. (2013) tested different levels of flours from the tilapia broiler industry in broiler feed and did not observe and effects of these levels on the deposition of protein and fat. According to these authors, the absence of effects on the values of fat and protein deposition for both thigh and overcook and for breast, may have occurred because the experimentais diets were isoenergetic and isonutritive, which providing the balanced daily intake of metabolizable energy and crude protein. Thus, it is probable that the absence of effect on the deposition of protein in the breast meat is associated with the fact that the experimentais diets were formulated to be isonutritive in all evaluated treatments.

The inclusion levels of purified glycerin did not influence $(p>0.05)$ the relative gizzard weights, nor the relative weight or length of the small intestine (Table 6). However, there was an effect $(p<0.05)$ on the relative weight of heart and liver, which increased linearly according to the increase of glycerin purified in the diets.

The results for the relative weight of the heart are in agreement with those found by Topal and Ozdogan (2013), who observed that birds fed a diet containing $8 \%$ glycerin had higher relative weight of the heart. However, the authors found no effect on the relative weight of liver and gizzard of broilers fed 4 or $8 \%$ crude glycerin. Nevertheless, according to the authors, the relative weight of some internal organs, such as the heart and liver, might be related to the weight gain of the birds. This may justify the increase in the relative weight of this organ in the present work since the GP of the birds increased linearly with the inclusion levels of purified glycerin in the diets. 
Table 6. Relative weight of the heart (HY), gizzard (GY), liver (LY), small intestine (SIY) and small intestine length (LSY) of broilers slaughtered at 42 days of age.

\begin{tabular}{|c|c|c|c|c|c|c|c|c|c|}
\hline \multirow[b]{2}{*}{ Variables } & \multicolumn{4}{|c|}{ Purified glycerin inclusion level } & \multirow{2}{*}{ Mean } & \multicolumn{3}{|c|}{$\mathrm{P}$} & \multirow{2}{*}{$\mathrm{CV}^{1}(\%)$} \\
\hline & 0 & 2 & 4 & 6 & & LE & $\mathrm{QE}$ & LD & \\
\hline HY (\%) & 0.37 & 0.37 & 0.42 & 0.44 & 0.40 & 0.003 & 0.460 & 0.326 & 7.36 \\
\hline $\mathrm{GY}^{2}(\%)$ & 1.30 & 1.33 & 1.30 & 1.31 & 1.31 & 0.983 & 0.833 & 0.777 & 11.48 \\
\hline $\mathrm{LY}^{3}(\%)$ & 1.71 & 1.89 & 1.84 & 1.97 & 1.85 & 0.005 & 0.656 & 0.077 & 5.03 \\
\hline $\operatorname{SIY}^{4}(\%)$ & 2.86 & 3.09 & 2.89 & 3.05 & 2.97 & 0.461 & 0.732 & 0.097 & 6.73 \\
\hline $\operatorname{LSY}^{5}(\mathrm{~m})$ & 161 & 1.67 & 1.64 & 1.77 & 1.67 & 0.051 & 0.497 & 0.252 & 5.55 \\
\hline
\end{tabular}

${ }^{1}$ Coefficient of variation $(\%)$.

$2,3,4,5 \hat{\mathrm{Y}}=\mathrm{NS}$.

$\mathrm{LE}=$ linear effect; $\mathrm{QE}=$ quadratic effect; $\mathrm{LD}=$ linearity deviation; $\mathrm{P}=$ probability of type $\mathrm{I}$ error at $5 \%$ using $\mathrm{F}$ test. Equation: $\mathrm{HY}$ $=0.3635+0.0124 \mathrm{IL}\left(\mathrm{P}=0.003 ; \mathrm{r}^{2}=0.87\right)$ e $\mathrm{LY}=1.743+0.00337 \mathrm{IL}\left(\mathrm{P}=0.005 ; \mathrm{r}^{2}=0.75\right)$, in which $\mathrm{IL}=$ purified glycerin inclusion level (\%).

Differing results were found by Sehu et al. (2012), who evaluated the levels of 0,5 , and $10 \%$ of glycerin in broiler feed and found that the relative weight of the liver, heart, and gizzard reduced with the inclusion level of $5 \%$ of the food in the diets.
It was observed that the levels of inclusion of purified glycerin in the diets did not affect the values of luminosity $\left(\mathrm{L}^{*}\right)$, red $\left(\mathrm{a}^{*}\right)$, yellow $\left(\mathrm{b}^{*}\right), \mathrm{pH}$, shear force, or baking weight loss (PPCO) of broiler chicks slaughtered at 42 days of age (Table 7).

Table 7. Average lightness $\left(\mathrm{L}^{*}\right)$, redness $\left(\mathrm{a}^{*}\right)$, yellowness $\left(\mathrm{b}^{*}\right) \mathrm{pH}$, temperature, shear force (FC) and weight loss per baking (PPCO) in the breast meat of broilers at 42 days of age according to the inclusion level of purified glycerin.

\begin{tabular}{|c|c|c|c|c|c|c|c|c|c|}
\hline \multirow{2}{*}{ Variables } & \multicolumn{4}{|c|}{ Purified glycerin inclusion level (\%) } & \multirow{2}{*}{ Mean } & \multicolumn{3}{|c|}{$\mathrm{P}$} & \multirow{2}{*}{$\mathrm{CV}^{1}(\%$} \\
\hline & 0 & 2 & 4 & 6 & & LE & $\mathrm{QE}$ & LD & \\
\hline $\mathrm{L}^{* 2}$ & 60.42 & 63.05 & 60.25 & 59.93 & 60.91 & 0.565 & 0.378 & 0.295 & 5.30 \\
\hline$a^{* 3}$ & 8.82 & 9.11 & 9.00 & 9.44 & 9.09 & 0.425 & 0.882 & 0.661 & 10.54 \\
\hline$b^{* 4}$ & 11.35 & 10.51 & 10.73 & 9.94 & 10.63 & 0.246 & 0.980 & 0.538 & 13.73 \\
\hline $\mathrm{pH}^{5}$ & 6,05 & 6.23 & 6.52 & 6.34 & 6.28 & 0.065 & 0.167 & 0.344 & 4.13 \\
\hline $\mathrm{FC}$ & 1.38 & 1.42 & 1.32 & 1.34 & 1.35 & 0.505 & 0.947 & 0.460 & 10.75 \\
\hline PPCO & 16.33 & 19.02 & 16.72 & 18.03 & 17.53 & 0.636 & 0.595 & 0.162 & 14.71 \\
\hline
\end{tabular}

${ }^{1}$ Coefficient of variation $(\%)$.

$2,3,4,5 \hat{\mathrm{Y}}=\mathrm{NS}$.

$\mathrm{LE}=$ linear effect; $\mathrm{QE}=$ quadratic effect; $\mathrm{LD}=$ linearity deviation; $\mathrm{P}=$ probability of type $\mathrm{I}$ error at $5 \%$ using $\mathrm{F}$ test.

Differing results for meat staining were found by Faria et al. (2013), who evaluated increasing levels of glycerin in broilers feeding and observed that the raw meat of the breast presented an orange color in general and that the increase of the levels of glycerin in the diets promoted a greater trend towards color red. However, there was no effect of the levels of glycerin in the diets on the shear force and the weight loss by cooking the meat.

\section{Conclusion}

The inclusion of $6 \%$ of purified glycerin in the diets was technically feasible for broilers from 8 to 42 days of age, provided that the diets are balanced to meet the nutritional requirements of the birds. 


\section{Acknowledgements}

Coordination for the Improvement Higher of Education Personnel (CAPES), for granting the scholarship, the Federal University of Tocantins (UFT), for the support and availability of facilities and the BONASA Foods and GRANFORTE for supplying the raw material to carry out the experiments.

"The development of this research benefited from the UFT Institutional Productivity Research Program (PROPESQ / UFT)".

\section{References}

ABD-ELSAMEE, M. O.; ABDO, Z. M. A.; ELMANYLAWI, M. A. F.; SALIM, I. H. Use of crude glycerin in broiler diets. Egyptian Poultry Science, Alexandria, v. 30, n. 1, p. 281-295, 2010.

DOZIER, W.A.; KERR, B. J.; BRANTON, S. L. Apparent metabolizable energy of crude glycerin originating from different sources in broiler chickens. Poultry Science, Champaign, v. 90, n. 11, p. 2528-2534, 2011.

DOZIER, W. A.; KERR, B. J.; CORZO, A.; KIDD, M. T.; WEBER, T. E.; BREGENDOAHL, K. Apparent metabolizable energy of glycerin for broiler chickens. Poultry Science, Champaign, v. 87, n. 2, p. 317-322, 2008.

EYNG, C.; NUNES, R. V.; MURAKAMI, A. E.; POZZA, P. C.; SCHERER, C.; SILVA, W. T. M.; BRUNO, L. D. Deposição de proteína e gordura nos cortes nobres de frangos alimentados com farinha de resíduos da indústria de fletagem de tilápia. Semina: Ciências Agrárias, Londrina, v. 34, n. 2, p. 875-882, 2013.

FARIA, P. B.; FIGUEIREDO, C. H.; LIMA, R. S.; NASCIMENTO, D. B.; SANTOS, C. C. S.; PINTO, A. M. B.; SILVA, J. L. Qualidade de carcaça e carne de frangos com uso de glicerina na alimentação. PUBVET, Londrina, v. 7, n. 24, p. 247-1631, 2013.

FREITAS, L. W.; MENTEN, J. F. M.; ZAVARIZE, K. C.; PEREIRA, R.; ROMANO, G. G.; LIMA, M. B.; DIAS, C. T. S. Evaluation of dietary glycerin inclusion during different broiler rearing phases. Brazilian Journal of Poultry Science, Campinas, v. 19, p. 91-96, 2017. Número Especial.

FRONING, G. W.; UIJTTENBOOGARTE, T. G. Effect of post mortem electrical stimulation on color, texture, $\mathrm{pH}$ and cooking loses of hold and cold deboned chicken broiler breast meat. Poultry Science, Champaign, v. 67, n. 11, p. 1536-1544, 1988.

GIANFELICI, M.F.; RIBEIRO,A.M.L.; PENZ JÚNIOR, A. M.; KESSLER, A. M.; VIEIRAM. M.; MACHINSKY, T. Determination of apparent metabolizable energy of crude glycerin in broilers chickens. Brazilian Journal of Poultry Science, Campinas, v. 13, n. 4, p. 255-258, 2011.

HENZ, J. R.; NUNES, R. V.; EYNG, C.; POZZA, P. C.; FRANK, R.; SCHONE, R. A. OLIVEIRA, T. M. M. Effect of dietary glycerin supplementation in the starter diet on broiler performance. Czech Journal of Animal Science, Kamýcká, v. 59, n. 12, p. 557-563, 2014.

HENZ, J. R.; NUNES, R. V.; POZZA, P. C.; FURLAN, A. C.; SCHERER, C.; EYNG, C.; SILVA, W. T. M. Valores energéticos de diferentes cultivares de milho para aves. Semina Ciências Agrárias, Londrina, v. 34, n. 5, p. 2403-2414, 2013.

JUNG, B.; BATAL, A. B. Nutritional and feeding value of crude glycerin for poultry. 1. Nutritional value of crude glycerin. Journal of Applied Poultry Research, Champaign, v. 20, n. 2, p. 162-167, 2011.

MCLEA, L.; BALL, M. E. E.; KILPATRICK, D.; ELLIOTT, C. The effect of glycerol inclusion on broiler performance and nutrient digestibility. British Poultry Science, London, v. 52, n. 3, p. 368-375, 2011.

MONGIN, P. Recent advances in dietary cation-anion balance: applications in poultry. Proceedings Nutrition Society, Cambridge, v. 40, n. 3, p. 285-294, 1981.

OLIVEIRA NETO, A. R. D.; OLIVEIRA, R. F. M. D.; DONZELE, J. L.; ROSTAGNO, H. S.; FERREIRA, R. A.; MAXIMIANO, H. D. C.; GASPARINO, E. Efeito da temperatura ambiente sobre o desempenho e características de carcaça de frangos de corte alimentados com dieta controlada e dois níveis de energia metabolizável. Revista Brasileira de Zootecnia, Viçosa, v. 29, n. 1, p. 183-190, 2000.

OLIVEIRA, D. D.; PINHEIRO, J. W.; OBA, A.; FONSECA, N. A. N. Desempenho de frangos de corte alimentados com glicerina pura. Semina Ciências Agrárias, Londrina, v. 34, n. 6, p. 4083-4092, 2013. Suplemento 2.

ROMANO, G. G.; MENTEN, J. F. M.; FREITAS, L. W.; LIMA, M. B.; PEREIRA, R.; ZAVARIZE, K. C.; DIAS, C. T. S. Effects of glycerol on the metabolism of broilers fed increasing glycerine levels. Brazilian Journal of Poultry Science, Campinas, v. 16, n. 1, p. 97-106, 2014.

ROSTAGNO, H. S.; ALBINO, L. F. T.; DONZELE, J. L.; GOMES, P. C.; OLIVEIRA, R. F.; LOPES, D. C.; FERREIRA, A. S.; BARRETO, S. L. T. Tabelas 
brasileiras para aves e suínos composição de alimentos e exigências nutricionais. 3. ed. Viçosa: UFV, Imprensa Universitária, 252 p, 2011.

SCHERER, C.; FURLAN, A. C.; MARTINS, E. N.; SCAPINELLO, C.; TON, A. P. S. Exigência de energia metabolizável de codornas de corte no período de 1 a 14 dias de idade. Revista Brasileira de Zootecnia, Brasília, v. 40, n. 11, p. 2496-2501, 2011.

SEHU, A.; KUCUKERSAN, S.; COSKUN, B.; KOKSAL, B. H.; CITIL, O. B. Effects of dietary glycerol addition on growth performance, carcass traits and fatty acid distribution in cloacal fat in broiler chickens. Revue de Médecine Vétérinaire, Toulouse, v. 163, n. 4, p. 194200, 2012.

SEHU, A.; KUCUKERSAN, S.; COSKUN, B.; KOKSAL, B. H. Effects of graded levels of crude glycerine addition to diets on growth performance, carcass traits and economic efficiency in broiler chickens. Kafkas Universitesi Veteriner Fakultesi Dergisi, Kars, v. 4, n. 19, p. 569-574, 2013.
SILVA, C. L. S.; MENTEN, J. F. M.; TRALDI, A. B.; PEREIRA, R.; ZAVARIZE, K. C.; SANTAROSA, J. Glycerine derived from biodiesel production as a feedstuff for broiler diets. Brazilian Journal of Poultry Science, Campinas, v. 14, n. 3, p. 159-232, 2012.

SILVA, D. J.; QUEIROZ, A. C. Análise de alimentos: métodos químicos e biológicos. 3. ed. Viçosa: UFV. 165 p, 2002.

SILVA, M. C.; VAZ, R. G. M. V.; RODRIGUES, K. F.; SILVA, G. F.; SOUSA, L. F.; FONSECA, F. L. R.; CAMPOS, C. F. A.; AUGUSTO, W. F.; PARENTE, I. P.; BEZERRA, L. S. Glicerina purificada em dietas balanceadas para frangos de corte dos 22 aos 42 dias de idade. Semina: Ciências Agrárias, Londrina, v. 38, n. 4, p. 2083-2090, 2017.

TOPAL, E.; OZDOGAN, M. Effects of glycerol on the growth performance, internal organ weights, and drumstick muscle of broilers. Journal of Applied Poultry Research, Champaign, v. 22, n. 1, p. 146-151, 2013. 
